\title{
Montesquieu on Cicero. Historiographical, political, and philosophical dimensions of a modern portrait
}

\section{Introduction}

“Cicéron selon moi est un des grans esprits qui aye jamais êté. L'ame toûjours belle lorsqu'elle n'etoit pas foible”. ${ }^{1}$ This apparently contradictory pensée is emblematic of the portrait of Marcus Tullius Cicero by Charles-Louis de Secondat, baron de la Brède et de Montesquieu. Since his early works he had displayed an ambivalent attitude towards Cicero, oscillating between admiration and criticism about the many-sided personality of the republican orator.

This mixture of praise and disapproval is part of a long-standing interpretative tradition, ${ }^{2}$ which was affected by the changes concerning the authority of ancient examples during Enlightenment, especially in France. Cicero played an important role in rhetorical education and Ciceronian Latin came also to be the official language of the Church and intellectuals. Nevertheless, Montesquieu asserts that "on ne peut jamais quitter les Romains". ${ }^{3}$

Although defining Montesquieu as part already of French Enlightenment may be controversial, it is undisputed that he lived in a period of increasing self-affirmation against philosophical, political and religious backgrounds, influencing his intellectual profile. However, he refused to abandon ancient authors, believing that they could still be source of valid political lessons:

J'ai eu toute ma vie un goût décidé pour les ouvrages des anciens. Ayant lu plusieurs critiques faites de nos jours contre les anciens, j'ai admiré plusieurs de ces critiques, mais j'ai admiré toujours les anciens.

1 Mont. Pensées 1.773 (Dornier 2013): "Cicero, in my opinion, is one of the greatest minds that has ever been. The soul always beautiful when was not weak". The quotations in French are freely translated by the author in footnotes. Reference editions are given in brackets after each quotation.

2 However, it goes back to a tradition cultivated since the Augustan Age. See La Bua 2019, 100 182.

3 Mont. EL 11.13 (Murachco 2005): "we can never leave the Romans”. 
Montesquieu paradoxical passion for the Ancient World and praise of modern innovations shaped a very peculiar portrait of Cicero that includes, at least, three aspects: Cicero as historiographical source, as historical figure and as philosopher. Hoping to obtain a comprehensive portrait that may clarify relevant traits of Cicero's modern image and his role in Montesquieu's historical and political thought, this paper aims to examine several works written by the Baron de la Brède, in which Cicero's life and ideas are discussed or his texts are used for argumentation.

\section{Cicero as historiographical source}

On the portrait of Cicero as a historiographical source in Montesquieu we are allowed to pinpoint which Ciceronian texts were available to the French philosopher. This is also preliminary to drawing a comprehensive picture of Cicero in Montesquieu's work. An inventory of the sources on Rome's republican history used by Montesquieu may be then a useful starting point. I will examine three significant works on Roman history.

In Dissertation sur la politique des Romains dans la religion (1716), Montesquieu focuses on the importance of religion in Roman politics. His historical approach demands several and distinct classical works. He mentions Livy, Suetonius, Macrobius, Valerius Maximus, Saint Augustin and Tacitus. In Considérations sur les causes de la grandeur des Romains et de leur décadence (1734), an intellectually mature Montesquieu aims to explore the plurality of causes of Roman political events. Such robust enterprise demanded a considerable increase on the number of sources and a qualitative shift on their use. In the chapters until Augustan Age, he quotes again Livy, Tacitus, Valerius Maximus, adding Polybius, Dionysius of Halicarnassus, Plutarch, Aulus Gellius, Florus, Frontinus, Appian, Dion and Sallust. Finally, in De l'esprit des lois (1748), his magnum opus, the pivotal argument on plurality of causes that give birth to political events is expanded. On analyzing the diversity of political experiences, Montesquieu identifies the intervention of cultural, legal, geographical, climatical, monetary and commercial factors, which indicate that each political organization have a reason to be so and they hardly can be classified according to abstract types of government. He also applies this reading to ancient civilizations, including Greece and Rome. For this purpose, the author uses Republican sources, such as Dionysius of Halicarnassus, Plutarch, Florus, Cornelius Nepos, Sallust, Tacitus, Dion Cassius, Suetonius, Julius Cesar, Valerius Maximus, Aulus Gellius, Polybius and Appian. 
What about Cicero? The Roman orator is one of the most referenced authors. In Dissertation, Montesquieu quotes De legibus, De senectute, De divinatione and De natura deorum. In Romains, a much larger text, he indicates Tusculanae disputationes, De officiis, Ad Atticum, Ad familiares and Ad Brutum. But there is a qualitative difference between the uses of Cicero in both texts: the quotations in the latter are more harmonious with the issues discussed and, for this reason, explored with considerable depth. The first direct quotation is a long transcription of the letter 4.18 from Cicero to Atticus, used to show the corruption of customs. ${ }^{4}$ Although Montesquieu had already made his point, he did not have enough material to support his argumentation, which he found in a Ciceronian text. Cultural aspects like this often find its origin in Cicero. Illustratively, Montesquieu evokes him to show how the Romans considered trade and arts as occupations of slaves, ${ }^{5}$ or to reinforce foreigners' habit of building temples to their former governors. ${ }^{6}$ Cicero is also used in the description of the profiles and deeds of great Republican figures, such as Sulla's tyrannical actions, ${ }^{7}$ and Pompey, whom Cicero accuses of being slow in certain quarrels with Caesar, an opinion endorsed by Montesquieu. ${ }^{8}$

Finally, Cicero is of the greatest importance to the discussion of the decline of the Republic in the Romains. According to Montesquieu, political anarchy favored the ambitions of political leaders. This was the perspective by which he looked at the triumvirate of Pompey, Crassus, and Caesar, who established impunity for all public crimes and eliminated any mechanism to prevent the corruption of customs. Instead of being good lawmakers, they worked to make their fellow citizens' situation worse. ${ }^{9}$ Still, some resisted. In a letter, Brutus states that he would kill his father just the same way he did. Nevertheless, such spirit of freedom was gradually lost: conspiracies would be reborn continually. ${ }^{10}$ In a conclusive tone, Montesquieu points out how it is possible to see the decline "dans les lettres de quelques grands hommes de ce temps-là", quoting

4 Mont. Romains 74 (Montesquieu 1796), citing Cic. Att. 4.18.

5 Mont. Romains 76 (Montesquieu 1796), citing Cic. off. 1.42.

6 Mont. Romains 91 (Montesquieu 1796), citing Cic. Att. 5 [21.7]. Montesquieu sometimes cites inaccurately and loosely, which has been preserved in this and the following footnotes.

7 Mont. Romains 77-78 (Montesquieu 1796), citing Cic. off. 2.8.

8 Mont. Romains 85 (Montesquieu 1796), citing Cic. fam. 15.15.

9 Mont. Romains 98 (Montesquieu 1796). Cela se voit bien dans les Lettres de Ciceron à Atticus. 10 Mont. Romains 88 (Montesquieu 1796), citing Cic. ad Brut. 16. 
Cicero as the author of most of them, a better source for knowing the despair of principal men than the speeches of historians. ${ }^{11}$

However, Cicero is an occasional source in De l'esprit. When invoked to detail the legal-institutional structure of the Roman Republic, he enables Montesquieu to describe the proceedings of judgment, ${ }^{12}$ the exile of defendants before trial ${ }^{13}$ and the lese-majesty crime according to Sulla's law. ${ }^{14}$ Relying on Cicero, he could explain how censorship worked, ${ }^{15}$ pointing to the composition of the populus each five years; ${ }^{16}$ similarly, he described the origin of the praetura, focusing on its significance to the defense of liberty. ${ }^{17}$ Cicero is also mentioned in order to understand the variability of societies, governments and legal provisions, such as divorce, ${ }^{18}$ increase of usury in elections time ${ }^{19}$ and the Gabinia Law prohibitions. ${ }^{20}$ These references impelled Montesquieu to develop investigations on the origins and content of the aforementioned law, which reveal how Ciceronian texts are not only informational material but also responsible for arousing legal and historical curiosity of interpreters. In other words, Cicero, like other ancients, is not merely a topoi reservoir for rhetorical strengthening. A good example is the discussion on testaments. Although wills were unwritten and without formalities, ${ }^{21}$ some jurists were uncertain if women could be heirs. Montesquieu evokes Cicero to outline possible interpretations on the matter, considering the original aims of the Gabinian Law, ${ }^{22}$ at the end endorsing his defense of the legitimacy of female heirs. ${ }^{23}$ The great care in following different Ciceronian passages to support an argumentative line shows how they were starting points for reflections. ${ }^{24}$

11 Mont. Romains 86-87 (Montesquieu 1796): "in the letters of some great men of that time", citing Cic. am. 9.15 and the letters to Servius Sulpicius.

12 Mont. EL 11.18 (Murachco 2005), citing Cic. Brut. 106.

13 Mont. EL 6.5 (Murachco 2005), citing Cic. Caecin. 98.

14 Mont. EL 16 (Murachco 2005), citing Cic. Clu. 3; Pis. 21; Verr. 2.5; fam. 3.2.

15 Mont. EL 8.14 (Murachco 2005), citing Cic. Att. 4.10; 15. Before, he cites Plut. Cic. [29-30; 34].

16 Mont. EL 11.17 (Murachco 2005).

17 Mont. EL 11.18 (Murachco 2005), citing Cic. Clu. 43.

18 Mont. EL 16.16 (Murachco 2005), citing Cic. Phil. 2.[69] (references in brackets are passages quoted by Montesquieu, but not fully indicated).

19 Mont. EL 22.22 (Murachco 2005), citing Cic. Att. 6.15; 16.

20 Mont. EL 22.22 (Murachco 2005), citing Cic. Att. 5.21.12; 6.1.

21 Mont. EL 27 (Murachco 2005), citing Cic. de orat. 1.[228].

22 Mont. EL 27 (Murachco 2005), citing Cic. fin. 2.[55]; 3.58; Verr. 2.1.[107]; Caecin. [99].

23 Mont. EL 27 (Murachco 2005), citing Cic. Verr. 2.1.107; 2.1.104; 2.1.42.

24 Mont. EL 27 (Murachco 2005). After quoting Cic. fin. 2.[54-55], he states: "je ferai ici quelques réflexions" (“I will do here some reflections”). 
There are also important connections between Cicero and liberty, a central issue to Montesquieu. ${ }^{25}$ Indeed, he admits a strong attachment to liberty in Rome, something firmly defended by Cicero. ${ }^{26}$ For both of them, "il n'y a point de mot qui ait reçu plus de différentes significations, et qui ait frappé les esprits de tant de manières, que celui de liberté". ${ }^{27}$ It implies the refusal of privileges, laws made against particular citizens. Cicero wanted their abolition because he believed that "la force de la loi ne consiste qu'en ce qu'elle statue sur tout le monde". ${ }^{28}$ Montesquieu disagrees. For him, a "veil on liberty" is admissible in certain moments. He forgets Cicero's concerns with aequitas, ${ }^{29}$ but this disagreement reveals his independence from the authority of classical writers, adopting a critical sense. Nevertheless, this hermeneutic autonomy could also lead to follow Ciceronian opinions, as when qualifying the Agrarian laws as disastrous ${ }^{30}$ or the creation of tribunes as a contribution to the welfare of the Republic because people's power is terrible without a chief. ${ }^{31}$ This also happens when he discusses the causes of decline of the Republic, already announced in Cicero's criticism of Rome being, simultaneously, world dominator and universal trading agent, ${ }^{32}$ a dangerous and unbalanced combination. ${ }^{33}$ He also warned about the secret vote, rejected because "il faut que le petit peuple soit éclairé par les principaux, et contenu par la gravité de certains personnages". ${ }^{34}$ Liberty was gradually weakened, but there was an alternative: tyrannicide. ${ }^{35}$

This discussion on liberty revels that the Romans had qualities still valid for modern men. For example, the Twelve Tables were "a model of precision", to the point that "les enfants les apprenaient par cœur", as in De legibus. ${ }^{36}$ However, in Montesquieu's time was no longer possible to agree with all ancient laws and

25 Perhaps one of the intellectual fathers of liberalism, as discussed in Spector 1998; 2010; 2012.

26 See Santos 2018a.

27 Mont. EL 11.2 (Murachco 2005): "there is no word which has received more different meanings, and which has struck the minds in so many ways, than that of liberty", citing Cic. Att. 6.1.15 without reference.

28 Mont. EL 12.19 (Murachco 2005): "the force of the law consists only in that it rules over everyone", citing Cic. leg. 3.44.

29 For aequitas in classical Roman law, see Santos 2018b.

30 Mont. EL 26.15 (Murachco 2005).

31 Mont. EL 5.11 (Murachco 2005), citing Cic. leg. 3.[24].

32 Mont. EL 20.4 (Murachco 2005), citing a fragment from Cic. rep. 4.7, probably from Non. 24.15.

33 Mont. EL 26.16 (Murachco 2005), citing Cic. leg. 1.4.

34 Mont. EL 2.2 (Murachco 2005): "the common people must be enlightened by the most important ones, and contained by the seriousness of certain characters".

35 Mont. EL 12.18 (Murachco 2005), citing Cic. inv. 2.[144].

36 Mont. EL 29.16 (Murachco 2005): "the children learnt them by heart”, citing Cic. leg. 1.[4]. 
practices, such as killing children with birth defects. The Baron de la Brède recognizes precisely that the modern men can and must use their critical skills to evaluate and judge other realities, including the products from the past. ${ }^{37}$ But even if they can act and know better, Roman examples remain important for political reflections. The experiences and customs narrated by Cicero $^{38}$ and the Republican episodes of fight for freedom could help French intellectuals to deal with a political Régime which was becoming Ancien.

Indeed, in Montesquieu, the classics are simultaneously messengers, rhetorical topoi and inspirations. Therefore, Cicero is not a historiographical source in contemporary sense. Montesquieu wants to keep him as a real companion in his investigative journey, helping the author to build up solid arguments. An intimacy so far from scientific history is an element that corroborates the thesis that classifies Montesquieu as a pioneer of philosophy of history. ${ }^{39}$ In fact, not only he connects realistic interpretations with a political sphere "daughter of history", ${ }^{40}$ but also tries to discover universal principles of history, which is interpreted as a moving totality full of non-reducible causes ${ }^{41}$ and endowed with meanings, ${ }^{42}$ according to a mixture of Newtonian influence with Aristotelian heritage. ${ }^{43}$ This was only possible since he was aware of his privileged position to learn and write history, ${ }^{44}$ knowing that historians were, above all, "examinateurs severes des actions de ceux qui ont paru sur la terre", as the "magistrats d'Egypte qui apelloient en jugement l'ame des tous les morts". ${ }^{45}$

Montesquieu does not mourn for ancient times. Rome is no longer a reference for moral or political discourse or a well of timeless examples, ${ }^{46}$ an effect

37 Mont. EL 23.23 (Murachco 2005), citing Cic. leg. 3.[19].

38 Mont. EL 19.27 (Murachco 2005), citing Cic. Phil. 2.69; Mont. Pensées 1.9 (Dornier 2013). 39 For Montesquieu as a philosopher of history or not, see Gibbon 1761, 108; Cassirer 1992, 282; Meinecke 1943; Carrithers 1986; Santos 2006. It is noteworthy the opinion of Rain, to whom Montesquieu introduces much more innovations than Voltaire's Histoire de Charles XII, published three years after Romains. See Rain 1952, 198.

40 Ehrard 1965, 10.

41 Althusser 1992, 43; 54.

42 Meinecke 1943, 141.

43 Goyard-Fabre 1993, 2-12; 55-68.

44 Mont. Pensées 2.1183 (Dornier 2013): “Je suis dans des circonstances les plus propres du monde pour écrire l'histoire" ("I am in the most propitious circumstances in the world to write the history").

45 Mont. Pensées 2.1260 (Dornier 2013): "Severe examiners of the actions of those who have appeared on the earth", as the "magistrates of Egypt who call the soul of all the dead to judgement".

46 Senarclens 2003, 11. 
of the quarrel between the ancients and the moderns. ${ }^{47}$ As Montesquieu puts it: "Il faut conaitre les choses anciennes non pas pour changer les nouvelles, mais afin de bien user des nouvelles". ${ }^{48}$ Cicero enters the scene: he witnessed the last sighs of the Republic, but was also a writer aware of the signs of ruin, as appears in his letters, "un monument bien authentique de la corruption romaine". ${ }^{49}$

\section{Cicero as historical and political figure}

The discovery of Cicero as a historiographical source helps to interpret him as a political character. First, it is necessary to understand the predominant view on Cicero in the XVIII century.

An interesting example is provided by another French philosopher, Voltaire. He had been outraged at Cicero's characterization in Crebillon's play Catilina, in which the consul was stripped of glory in the conspiracy. Voltaire soon elaborated Rome Sauvée, ou Catilina to "show Cicero in glowing lights". ${ }^{0}$ For him, Cicero's name "est dans toutes les bouches, ses écrits dans toutes les mains”, all know when he was "à la tête de Rome". ${ }^{51}$ In charge of public affairs, he still found time to learn Greek philosophy, becoming "le plus grand philosophe des Romains, aussi bien que le plus eloquent”. ${ }^{52}$ Voltaire's passion for Cicero was so intense that he emulated the consul in private rehearsals, occasions in which "le personnage se confondait avec le poëte", as Condorcet remarked. ${ }^{53}$

The young Montesquieu had a similar exaltation, but contrasted it with critical disapprobation. The starting point is his Discours sur Cicéron. ${ }^{54}$ The text begins with a strong statement: "Cicéron est, de tous les anciens, celui qui a eu le plus de mérite personnel, et à qui j'aimerois mieux ressembler”. ${ }^{55} \mathrm{He}$ wants to be

47 Pii 1997, 29.

48 Mont. Pensées 3.1795 (Dornier 2013): "One must know the old things not to change the new ones, but in order to use the new ones well".

49 Mont. Pensées 3.1669 (Dornier 2013): “A very authentic monument of Roman corruption”; Andrivet 2013.

50 Sharpe 2015, 329.

51 Voltaire 1753, III-IV: "Is in everyone's mouth, his writings in everyone's hand"; "at the head of Rome".

52 Voltaire 1753, V-VI: "The greatest philosopher of the Romans, as well as the most eloquent". See also the laudation in the preface to Lettres de Memmius a Cicéron (Moland 1879, 438).

53 Condorcet 1795, 103-104: "The character merged with the poet".

54 See also Santos 2018c.

55 Mont. Discours sur Cicéron 1 (Montesquieu 1892): “Cicero is, of all the ancients, the one who had the most personal merit, and whom I would like better to resemble”. 
like Cicero especially because he "ait soutenu de plus beaux et de plus grands caractères", ${ }^{56}$ obtaining a solid glory "par des routes moins battues". ${ }^{57}$

Ciceronian eloquence is lauded as grandiose, majestic, and heroic. Using it he triumphed over Catiline, stood up against Anthony and wept for the dying liberty. Furthermore, he drew the portrait of great men with lively feelings, which is why Montesquieu claims not to know to whom he would like to resemble more, "ou au héros, ou au panégyriste". ${ }^{58}$ He disagrees with the "idée bien fausse" ${ }^{59}$ created by interpreters accustomed to measure their heroes against Q. Curtius Rufus' Alexander, ${ }^{60}$ characterizing Cicero as a "homme foible et timide". ${ }^{61}$ If he avoided the danger, it was because he knew it. His passions and fears were submitted to wisdom and reason. Montesquieu concludes: there is no greater example of strength and courage than the accusation against Anthony in the senate or the fact that all "les ennemis de la République furent les siens [...], tous les scélérats de Rome lui déclarèrent la guerre" ${ }^{62}$

However, sometimes "la force de son esprit sembla l'abandonner". ${ }^{63}$ For instance, when Rome was being devastated by factions, Cicero retired to private to write: "sa philosophie fut moins forte que son amour pour la République". ${ }^{64}$ Nevertheless, he kept an eye on the clashes between Caesar and Pompey, lamenting how citizens had not listened to his warnings about the former, what could have spared much suffering for the Republic. ${ }^{65}$ If he took long time to decide whom he would follow, he later acted against Caesar as a true "républicain". Liberty was destroyed, so philosophy was a legitimate consolation, which yielded "ces beaux ouvrages qui seront admirés par toutes les sectes et dans toutes les révolutions de la philosophie". ${ }^{66}$ And, as soon as liberty reap-

56 Mont. Discours sur Cicéron 1 (Montesquieu 1892): "Had sustained the most beautiful and the greatest characteristics".

57 Mont. Discours sur Cicéron 1 (Montesquieu 1892): "By less beaten paths".

58 Mont. Discours sur Cicéron 2 (Montesquieu 1892):"Or to the hero, or to the panegyrist”.

59 Mont. Discours sur Cicéron 4 (Montesquieu 1892): "Very wrong idea".

60 Montesquieu refers to Historiae Alexandri Magni.

61 Mont. Discours sur Cicéron 4 (Montesquieu 1892): "Weak and shy man”.

62 Mont. Discours sur Cicéron 5 (Montesquieu 1892): "The enemies of the Republic were his (...), all the scelerats of Rome declared war on him".

63 Mont. Discours sur Cicéron 5 (Montesquieu 1892): "The strength of his spirit seemed to abandon him".

64 Mont. Discours sur Cicéron 5 (Montesquieu 1892): "His philosophy was less strong than his love for the Republic".

65 Montesquieu makes a free translation of Cic. Phil. 2.24.

66 Mont. Discours sur Cicéron 7 (Montesquieu 1892): "These beautiful works which will be admired by all sects and in all revolutions of philosophy”. 
peared, he returned to politics. In fact, it was his name that Brutus, the liberator, called by:

\begin{abstract}
Mais, lorsque les conjurés eurent commis cette grande action qui étonne encore aujourd'hui les tyrans, Cicéron sortit comme du tombeau, et ce soleil, que l'astre de Jules avoit éclipsé, reprit une nouvelle lumière. Brutus, tout couvert de sang et de gloire, montrant au peuple le poignard et la liberté, s'écria : “Cicéron!” Et, soit qu'il l'appelât à son secours, soit qu'il voulût le féliciter de la liberté qu'il venoit de lui rendre, soit enfin que ce nouveau libérateur de la patrie se déclarât son rival, il fit de lui dans un seul mot le plus magnifique éloge qu'un mortel ait jamais reçu. ${ }^{67}$
\end{abstract}

Anthony reacted. He took the power for himself and, proud of his own eloquence, no longer feared Cicero's: spoke against him in the senate, “mais il fut bien étonné de trouver encore dans Rome un Romain". ${ }^{68}$ Despite the brilliance of his last speeches, Cicero was immolated in the "indigne réconciliation"69 between Octavian and Anthony.

It is a sweet portrait. However, later, Montesquieu added a comment to Discours, informing that he did not published it because it had "l'air de panégyrique" ${ }^{70}$ Indeed, he was then under the effect of Ciceronian works that he had read to support Dissertation in 1716. But in 1734 his vision changed: in Romains, Cato had "the ethical laurel". ${ }^{71}$ Why?

First, Montesquieu agrees with Cicero about Caesar's tyrannical derangements, ${ }^{72}$ but believes that he could have acted differently, as he once confessed. ${ }^{73}$ Later, Cicero is criticized because, in order to get rid of Anthony, he made "the wrong choice" to work for the elevation of Octavian: instead of making Caesar

67 Mont. Discours sur Cicéron 7 (Montesquieu 1892): "However, when the conspirators had committed this great act, which still astonishes tyrants today, Cicero emerged as if from the tomb, and this sun, which the star of Julius had eclipsed, resumed a new light. Brutus, all covered in blood and glory, showing the people the dagger and the freedom, cried: 'Cicero!' And, either that he called him to his rescue, or that he wanted to congratulate him on the freedom which he had just restored, or finally that this new liberator of the country declared himself his rival, he made him in only one word the most magnificent praise a mortal has ever received".

68 Mont. Discours sur Cicéron 8 (Montesquieu 1892): "But he was astonished to find still in Rome a Roman”.

69 Mont. Discours sur Cicéron 8 (Montesquieu 1892): "Unworthy reconciliation”.

70 "The air of panegyric".

71 Sharpe 2015, 333.

72 Mont. Romains 86 (Montesquieu 1796), citing Cic. fam. 9.15.

73 Mont. Romains 90-91 (Montesquieu 1796), citing Cic. Att. 14.10. 
be forgotten, placed him before everyone's eyes. ${ }^{74}$ Cato would have acted in a different way.

Je crois que, si Caton s'étoit réservé pour la république, il auraoit donné aux choses tout un autre tour. Cicéron, avec des parties admirables pour un second rôle, étoit incapable du premier: el avoit un beau génie, mais une ame souvent commune. L'accessoire chez Cicéron, c'étoit la vertu; chez Caton, c'étoit da gloire. Cicéron se voyoit toujours le premier; Caton s'oublioit toujours. Celui-ci vouloit sauver la république pour elle-même, celui-là pour s'en vanter.

Je pourrois continuer le parallèle, en disant que, quand Caton prévoyoit, Cicéron craignoit; que là où Caton espéroit, Cicéron se confioit; que le premier voyoit toujours les choses de sang froid, l'autre au travers de cent petites passions. ${ }^{75}$

Cato is portrayed as a wise man who could have given a different future for the Republic. Cicero, in turn, is seen as impulsive and, though he did want to save Rome, was much more concerned with nourishing his vanity. He ended up giving the Republic an even more dangerous enemy: Octavian. ${ }^{76}$ Here he echoes the old anti-Ciceronian propaganda that Cicero was blind for the sake of glory, something that would not happen to Cato's strict moral. Here lies his fallibility. ${ }^{77}$

On the one hand, in Discours, Cicero's political struggles and eloquence are expressions of a fading republican era, still firmly defended against its enemies, as the corrupt Verres, the subversive Clodius and Catiline, or the ambitious Caesar and Anthony, always as a brilliant lawyer or tireless magistrate. On the other hand, in Romains, his political role is limited and, in relevant events, absent. The tone is incisively critical. But Montesquieu is aware of not confusing facts with old rhetoric laudations, as well as of not being blindly seduced by ancient prejudices against Cicero. For this reason, he points out to a natural "vanité chez les Romains", who urged friends to praise in their writings, such as Tribonius to Cicero $^{78}$ or Cicero himself to Lucceius. ${ }^{79}$ This "amour immoderé pour estre celebré"

74 Mont. Romains 91-92 (Montesquieu 1796).

75 Mont. Romains 92 (Montesquieu 1796): "I believe that if Cato had reserved himself for the republic, he would have given things a whole new turn. Cicero, with admirable talents for a supporting role, was incapable of the leading one: he had a fine genius, but a soul often common. The accessory in Cicero was virtue; in Cato was the glory. Cicero always saw himself first; Cato always forgot himself. The latter wanted to save the republic for itself, the former to praise himself about it. I could continue the parallel, saying that, when Cato foresees, Cicero feared; that where Cato hoped, Cicero confided; that the former always saw things in cold blood, the latter through a hundred little passions".

76 Mont. Romains 92-93 (Montesquieu 1796).

77 Sharpe 2015, 333. See Stoner (p. 83-99) in this volume.

78 Cic. fam. 12.16. 
was part of Roman education ${ }^{80}$ and, although strange to modern men, uninterested in glory for posterity, ${ }^{81}$ it may be understandable why Cicero was perhaps so dominated by it.

In addition, Montesquieu did not pay much attention to the Catiline's conspiracy in Romains. Only in a fragment he writes that the episode was not so clear and brilliant as Cicero registered: it was a "dessein mal conçu, mal digeré, dificile à commaencer, impossible à finir, et qui etoit moins l'effet de l'embition que de l'impuisance et du désespoir". However, it deserves attention for the uniqueness of a general conspiracy for the destruction of Rome, a fame steamed only from the "scelerats qui la formerent", as recorded by Cicero. Once again "nous trouvons dans les lettres de Cicéron un monument bien authentique de la corruption romaine" 82 and its mediocre people. ${ }^{83}$

In other words, despite being a hesitant and fallible political actor, Cicero is indispensable as a privileged witness of republican history. If some judgments can be made concerning his actions, according to an old tradition not entirely rejected by Montesquieu, it is because of the abundant information found in his works, especially the private perspective of his letters, which closely follows events while revealing Cicero's feelings, doubts and subjectivity, something without comparison with other ancient figures. Montesquieu does not dare to forget him. He knows that to understand the role and the stature of other great men who lived in the late Republic, it is indispensable to understand their political, social and intellectual relations with the old consul. Directly or indirectly, as agent or witness, Montesquieu's republican Rome is Cicero's Rome.

\section{Cicero as philosopher}

Finally, as a philosopher, Cicero is also depicted as hesitant, but this is a signal of criticism of consolidated theoretical positions. The focus of Montesquieu is on the Ciceronian discussions on religion, which he interprets as very similar to the

79 Cic. am. 5.12.

80 Mont. Pensées 2.962 (Dornier 2013): "Vanity among the Romans"; “immoderate love to be celebrated".

81 Mont. Pensées 2.1552 (Dornier 2013).

82 Mont. Pensées 3.1669 (Dornier 2013): "Plan poorly conceived, badly digested, difficult to start, impossible to finish, and that was less the effect of ambition than of helplessness and despair"; "scelerats who formed it"; "we find in the letters of Cicero a very authentic monument of Roman corruption".

83 Mont. Pensées 3.1960 (Dornier 2013). 
paths of XVIII century French intellectuals, increasingly suspicious of religion, and of his own thought.

\subsection{Religion and politics}

Montesquieu had a general interest in religion. In Pensée 1946, the author registers a reflection on the origins of the notion of God and the ingenuity of man in the process of conceiving it. According to him, when man conceived God as material, imagination naturally attributed a human figure to the divinity, since he found nothing more beautiful than himself. It is in similar terms that the Epicurean Velleius concludes in De natura deorum (1.1-2). The same Ciceronian text will support another consequence: as the senses tell us that there are only substances with human figure endowed with reason, men believed that reason is inseparable from God. ${ }^{84}$ The critical tone is explicit: the mirroring of man in divinity, an argument true even for the Christian conception of God.

Montesquieu also points out how pagans believed not only in gods, but as well in natural manifestations. This is what Cicero's Stoic Balbus says: God partakes, by his nature, of all things (deus pertinens per naturam cuiusque rei). ${ }^{85} \mathrm{But}$ they had a feature missing in Christianity: in their world reigned a "esprit de tolérance et de douceur", all religions and theologies were equally good, and heresies, wars or religious disputes were unknown. In short, a very positive spirit, absent in modern Christianity. ${ }^{86}$ This picture proves Gay's opinion, who believed that Montesquieu's generation, like his own, "still knew a neutral zone where pagan and Christian could meet on relatively friendly terms". ${ }^{87}$

The recent discovery of Notes sur Cicéron, consisting of commentaries on Ciceronian philosophical works from a XVI century edition, has expanded knowledge about Montesquieu's reflections on religion. ${ }^{88}$ Right on the first observations, he defends Cicero's argument concerning the inadequacy of the vulgar opinion men have an innate idea of divinity or a natural knowledge of it. ${ }^{89} \mathrm{He}$ then concludes that atheism existed among ancient philosophers: nothing "ne détruit plus la [preuve] de l'existence de Di[eu]... que [les] différentes opinions

84 Mont. Pensées 3.1946 (Dornier 2013), citing Cic. nat. deor. 1.47-48.

85 Mont. Dissertation 201 (Montesquieu 1796), citing Cic. nat. deor. 2.71.

86 Mont. Pensées 2.1606 (Dornier 2013): "Spirit of tolerance and sweetness".

87 Gay 1967.

88 See details in Volpilhac-Auger 2013; Benítez 2012, 3.

89 Mont. Notes 40 -41 (Benítez 2012), commenting Cic. nat. deor. 1.1-2; Benítez 2012, 19. 
[des] $\mathrm{p}<$ hiloso $>$ phes et des législat[eurs] sur la divinité". ${ }^{90}$ Later, he moves on to criticize Roman religion. Credulity must be rejected, as in the dream preceding Caesar's death: ${ }^{91}$ ancient historians actually added fantastic elements to a life already "toutte remplie des miracles de la fortu[ne]". Indeed, episodes of premonition or divination show how men do things in a way they already had interest in doing. ${ }^{92}$ The religious phenomena are only justification or exaggeration about events, interests, desires, actions. How can it be admitted the existence of more prolific ages in miracles than others? The centuries more ignorant are also "les plus credules". On the one hand, we have "le bonheur de vivre [dans] un siecle fort éclairé". ${ }^{93}$ On the other hand, this is not the end of obscurantisms and superstitions. The analyses of ancient religions in Notes once again reflects opinions on Christianity. As Benitez puts it, the commentaries on pagan customs allow Montesquieu a "settling of scores with the Christian religion", ${ }^{44}$ explicit in comments like this:

J'aime a [m'en r]emettre a l'ecriture [et aux] conciles; mais pour [pas pour] le reste les Thomas [les J]ustin et les autres [Pères] qu'on appelle les [lumiè]res de l'eglise, (...) tous les [anciens] ecrivains enfin [bons e]t mauvais sacrez [et p]rophanes ont chez [moi] une egale authorité celle de la raison. ${ }^{95}$

In other words, more than any authority established by tradition, reason is the only criterion for judgement. Montesquieu sees a similar primacy of reason in Cicero's investigations on religion. In fact, the old consul was very rigorous when

90 Mont. Notes 44 (Benitez 2012): "Destroyed more the proof of the existence of God... than the different opinions of the philosophers and the legislators on the divinity", commenting Cic. nat. deor. 1.14. The Notes are composed of commentaries from different passages of Ciceronian works on religion. The texts are sometimes very fragmentary, which required the insertion of interpolations signs and missing or abbreviated words by Benítez in his edition. Though this procedure, it was possible to reconstruct the original sentences. In my translation in footnote, like the one above, I introduced punctuation to ensure the correct understanding of the passages.

91 Mont. Notes 106 (Benítez 2012).

92 Mont. Notes 112 (Benítez 2012): “All filled with the miracles of fortune”, commenting Cic. div. 1.119.

93 Mont. Notes 101-103 (Benítez 2012): "Ahe most credulous”; "the happiness of living in a very enlightened century".

94 Benítez 2012, 34.

95 Mont. Notes 108 (Benítez 2012): "I love to refer myself to the Scriptures and to the councils; but not for the rest. The Thomas, the Justins and the other Fathers, who are called the enlightened ones of the Church (...) all the ancient writers, finally, good and bad, sacred and profanes, have in me an equal authority: that of reason", commenting Cic. div. 1.62. 
facing arguments, suspecting ready answers and poets. ${ }^{96}$ If he lived in Modern Age, he would take the same critical posture concerning the precepts of Christianity: “[Ci]ceron guidé par les [lumièr]es de la raison naturelle [d]it qu'il n'etoit point [de la s]agesse de dieu de [parler] aux hommes sans [se fa]ire entendre”, reason why he "n'eut [pas é]té fort satisfait [des] propheties et de [l'Apo]calypso". One of his advantages was not to be under the yoke of Christian ideology: "son esprit n'etoit point nourry dans les mystères ny dans les [ténèbr]es ombres de la parabole". ${ }^{97}$ Therefore, he was also able to point out the political uses of religion throughout Roman history.

In Dissertation, Montesquieu affirms that the establishment of religion was as important to the first kings as to create laws and walls. The Roman legislators then "firent la religion pour l'État", while legislators of other peoples did "l'État pour la religion". For this reason, they could use the people's "crainte pour le conduire à leur fantaisie”. Later, religion became a mechanism of discipline for the construction of civilization. The access to sacred texts was then restricted to official interpretations, the activities of priests and diviners were regulated by the senate, as prescribed by the book of pontiffs, "dont Cicéron nous a conservé quelques fragments". ${ }^{98}$ In conclusion, superstition was an advantage to the Romans, for not all citizens were wise and the enraged people needed instruments of control:

La crédulité du peuple réparait tout chez les Romains: plus une chose était contraire à la raison humaine, plus elle leur paraissait divine. Une vérité simple ne les aurait pas vivement touchés: il leur fallait des sujets d'admiration, il leur fallait des signes de la divinité; et ils ne les trouvaient que dans le merveilleux et le ridicule. ${ }^{99}$

96 Mont. Notes 121-122 (Benítez 2012), commenting Cic. sen. 66.

97 Mont. Notes 118 (Benítez 2012): "Cicero, guided by the lights of natural reason, said that it was not intrinsic to the wisdom of God to speak to men without making himself understood"; "was not very satisfied with the prophecies and the Apocalypse"; "his spirit was not nourished in the mysteries nor in the dark shadows of the parable", commenting Cic. div. 1.131.

98 Mont. Dissertation 195 (Montesquieu 1796): "Made the religion for the State"; "the State for the religion"; "fear to lead them according to their will"; "of which Cicero preserved for us some fragments”, citing Cic. leg. 2.20-21.

99 Mont. Dissertation 195: "The credulity of the people repaired everything among the Romans: the more a thing was contrary to human reason, the more it appeared divine to them. A simple truth would not have touched them deeply: they needed subjects of admiration, they needed signs of the divinity; and they found it only in the marvellous and the ridiculous”, citing Cic. leg. 2.20-21. Montesquieu's interpretation here is very close to the reflections developed earlier in Polybius 4.56 and in Machiavelli's Discorsi sopra la prima deca di Tito Livio 1.11. 
Auguries and divinations were politically useful to great public men, as Cicero showed it in several passages. First, in De senectute, when Fabius, as augur, ruled that what was advantageous to the Republic was always under good auspices. ${ }^{100}$ Second, in De divinatione, when Marcellus defended that, in spite of their origin from popular credulity, the augurs came to be of public utility. ${ }^{101}$ The omens could be used as means "pour détourner le peuple d'une guerre qui aurait été funeste, ou pour lui en faire entreprendre une qui aurait pu être utile", ${ }^{102}$ but, at the same time, could make people believe that "les mauvais succès, les villes prises, les batailles perdues, n'étaient point l'effet d'une mauvaise constitution de l'État, ou de la faiblesse de la république, mais de l'impiété d'un citoyen, contre lequel les dieux étaient irrités”. ${ }^{103}$ For Montesquieu, men like Scaevola and Varro discovered the art of political secrets by admitting "qu'il était nécessaire que le peuple ignorât beaucoup de choses vraies, et en crût beaucoup de fausses". ${ }^{104}$ He claims his findings are not arbitrary: the proofs are in ancient authors such as Cicero.

Ceux qui lisent l'histoire romaine, et qui sont un peu clairvoyants, trouvent à chaque pas des traits de la politique dont nous parlons. Ainsi on voit Cicéron qui, en particulier, et parmi ses amis, fait à chaque moment une confession d'incrédulité, parler en public avec un zèle extraordinaire contre l'impiété de Verrès. ${ }^{105}$

Montesquieu sees superstition employed to sustain the Republic. Cicero revealed it in De divinatione: the magistrates governed under the auspices of religion. ${ }^{106}$ Since monarchy, religious elements penetrated political and juridical structures, like the procedures of war. Later on, religion became an instrument of foreign policy and civilizational improvement, because, in contact with other peoples, the Romans began to submit themselves to alien gods. It was a smart move

100 Mont. Dissertation 196 (Montesquieu 1796), citing Cic. sen. 4.

101 Mont. Dissertation 196-197 (Montesquieu 1796), citing Cic. div. 2.35.

102 Mont. Dissertation 197 (Montesquieu 1796): "To divert the people from a war that would have been fatal, or to make them undertake one that could have been useful".

103 Mont. Dissertation 199 (Montesquieu 1796): "Bad successes, cities taken, battles lost, were not the effect of a bad constitution of the State, or of the weakness of the republic, but of the impiety of a citizen, against whom the gods were angry".

104 Mont. Dissertation 200 (Montesquieu 1796): "That it was necessary for the people to ignore many true things, and to believe in many false ones".

105 Mont. Dissertation 200 (Montesquieu 1796): "Those who read Roman history, and who are a little clairvoyant, at every step find aspects of the politics that we are talking about. Thus, we see Cicero who, in particular, and among his friends, at every moment makes a confession of unbelief, speaking in public with extraordinary zeal against the impiety of Verres".

106 Mont. Dissertation 204 (Montesquieu 1796), citing Cic. div. 1.89. 
for conquered peoples to look at Rome "plutôt comme le sanctuaire de la religion que comme la maîtresse du monde". ${ }^{107}$ Montesquieu concludes that the Romans, in effect, had as their true great divinity "le génie de la république". ${ }^{108}$

In short, Cicero is a resource for modern philosophers to deal with issues they cannot face openly, like religion and its connection with politics. It is necessary to detail now how Ciceronian critical examinations are also important to Montesquieu's other concerns.

\subsection{A model of philosopher}

In Pensée 969, Montesquieu argues that, like all people who wish to flourish and to be happy, the Greeks sought to cultivate the spirit and acquire knowledge, reason why they began to develop philosophy. However, certain philosophers later on tried to eliminate the belief in gods. In the Roman world, Cicero was the first to translate into Latin the dogmas of Greek philosophy, leading then to a critical interpretation of religion. Montesquieu refers mainly to De natura deorum. In his opinion, Cicero's critical view "porta un coup mortel a la religion de Rome". ${ }^{109}$ Andrivet observes that Montesquieu appreciated the Ciceronian duality to preserve traditional religious beliefs and exercise his intellectual freedom. ${ }^{110} \mathrm{He}$ indeed wrote about "liberté de la philosophie", meaning a free usage of reason. To do so, according to Volpilhac-Auger, he relied on the great masters, starting with Cicero himself (or his Cotta), followed by Descartes, Malebranche, and Bayle. He connects his arguments to the authority of tradition, but is bold: freely using reason, he can propose a virulent criticism of Christianity, its theological foundations, dogmas, and practices. ${ }^{111}$ This is very well stated in a note about De natura deorum: “C'est nost <ra> e raison qui est donnée pour no [us] éclairer non pas ce[lle] des autres". ${ }^{112}$

It is also free reason that Montesquieu will employ in his evaluation of certain Cicero's interpretations. He does not consider all of Cicero's ideas satisfac-

107 Mont. Dissertation 206 (Montesquieu 1796): "Rather as the sanctuary of religion than as the mistress of the world”, citing Cic. nat. deor. 3.42. Similar passage in Mont. Notes 88 (Benítez 2012).

108 Mont. Dissertation 207 (Montesquieu 1796): “The genius of the republic".

109 Mont. Pensées 2.969 (Dornier 2013): "Dealt a fatal blow to the religion of Rome”.

110 Andrivet 2013.

111 Volpilhac-Auger 2013.

112 Mont. Notes 43 (Benitez 2012): "It is our reason that is given to clarify us, not that of others”, commenting Cic. nat. deor. 1.10 . 
tory, as in his great-unfinished project: Traité des devoirs. ${ }^{113}$ In 1725 , the author announced that the first chapters would involve subjects such as "l'honneur, la probité, l'humanité, l'amour de la patrie”, to "invite men to virtue". Later on, he announced the composition of a work on "the Duties of Man" ("les Devoirs de l'Homme"), theme "more difficult for a Christian philosopher to deal with" than to a pagan philosopher. He then concludes that "est utile que la Morale soit traitée en même temps par les chrétiens et par les philosophes, afin que les esprits attentifs voyent [...] combien peu de chemin il y a à faire pour aller de la philosophie au christianisme". ${ }^{114}$ Finally, in a letter dated to 1750, Montesquieu recounts that for some thirty years he had set out that project manly because of his delight with Cicero's De officiis, chosen as a model because the Stoics were those who "ont mieux traité cette matière des devoirs". However, he gave up, among other reasons, because Cicero's duties division was “trop vague". In spite of this negative observation, he then introduces a compliment: having "un rival tel que Cicéron" made his "esprit tombait devant le sien". ${ }^{115}$ In a Pensée, Montesquieu explains that Cicero divides the honest into four fields: attachment to sciences and search for truth, maintenance of civil society, greatness of soul and appropriateness of actions secundum ordinem et modum. The consul believed "qu'un bon citoyen doit plutôt s'employer pour sa patrie". ${ }^{116}$ Indeed, Montesquieu's great concern is to discuss the moral duties of man as citizen: "l'esprit du citoyen" is oriented to public welfare and civic duties. ${ }^{117}$ Nevertheless, Roman civic attitude was partly different from the Greek desire for freedom, honour, and glory for great deeds, as he concludes in ambiguous terms: "Le peuple de Rome avec une haine toujours active contre les nobles chang[e]a de moyens sans changer de fin d'abord il song[e]a à les abaisser en diminuant leurs privileges, et ensuite en augmentant l'authorité d'un seul". ${ }^{118}$

113 According to Pensées et fragments inédits, published in 1899.

114 Mont. Traité 66 (Laboulaye 1879): "It is useful that Morality is treated at the same time by Christians and by philosophers, so that attentive spirits see [...] how little way there is to go from philosophy to Christianity".

115 Mont. Correspondance, Lettre 518, a Mgr. de Fitz-James, October 8th, 1750, 304-305 (Gébelin/Morize 1914): "Have better dealt with this subject of duties"; "too vague"; "a rival such as Cicero"; "spirit fall in front of his".

116 Mont. Pensées 2.1263 (Dornier 2013): "That a good citizen should rather work for his country", citing Cic. off. $1.5-6$.

117 Mont. Traité, Pensée 2.1269 (Laboulaye 1879): “The spirit of the citizen”. See Fott 2002, 729730.

118 Mont. Pensées 3.1674: "The people of Rome, with an ever-active hatred against the nobles, changed their means without changing their ends; at first they thought of lowering them by decreasing their privilege, and then by increasing the authority of a single person”. 
These ideas from Traité are developed in De l'esprit and are clearly consistent with the Roman conception of citizenship, ${ }^{119}$ very well registered in Ciceronian reflections. ${ }^{120}$ Roman moral framework was important to Montesquieu because it was a base for the construction of his own framework of duties, destined for men of the present. An enterprise like that implied the defense of intertemporal validity of certain civic duties enunciated by Cicero. Conscience, for instance, had a relevant role, as in the story of the merchant of honey in De officiis, an example of how pagan philosophers discussed conscience with such candor of soul and delicacy that even Christians did not dare to judge it inadequate. Montesquieu concludes: the Christian duties were already part of pagan ideals of humanity and love for common good. ${ }^{121}$ Therefore, there is no incompatibility between Christian and pagan morality, like in the love for motherland, recorded in Greek and Roman histories, but now in decline. ${ }^{122}$

These passages provide new insights into how the quarrel of the ancients and the moderns still reverberates in Montesquieu's reflections. He declares his enjoyment in observing their contrapositions: "J'aime a voir les querelles des anciens et des modernes, cela me fait voir qu'il y a de bons ouvrages parmi anciens et les modernes". ${ }^{123}$ As he concludes, if there are also good works among the ancients, this is enough to justify his great appreciation for them: "J'avoue mon goût pour les anciens cette antiquité m'enchante". ${ }^{124}$ As for the cities: "Rome antica e moderna m'a toujours enchanté". ${ }^{125}$

Montesquieu's approach to Cicero reverberates such quarrel. Even in the complimentary tone of Discours, qualities and defects coexist. On the one hand, he is the guarantor of freedom, faithful to the duties as a citizen, besides being a great intellectual. On the other hand, his great philosophical face is not altogether perfect. Fott understands that Montesquieu would argue that most modern "are wiser than most people in ancient times and probably even that the wisest moderns excel the wisest ancients: something seems to have been

119 Nicolet 1976.

120 See Santos 2018a: 119-153.

121 Mont. Pensées 2.924 (Dornier 2013), citing Cic. off. 3.12.

122 Mont. Pensées 1.221 (Dornier 2013).

123 Mont. Pensées 1.111 (Dornier 2013): "I love to see the quarrels of the ancients and the moderns; it makes me see that there are good works among ancients and moderns”. A slightly different version is Mont. Pensées 1.171 (Dornier 2013).

124 Mont. Pensées 1.110: "I admit my taste for the ancients, this antiquity enchants me". 125 Mont. Correspondance, Lettre LXXII, A M. le Grand Prieur Solar, ambassadeur de Malte à Rome (Gébelin/Morize 1914): "Rome antica and moderna always enchants me". 
lacking in Cicero's philosophizing because he was able only to "destroy errors" and not "discover truth". ${ }^{126}$ I do not think this interpretation is entirely correct.

It is clear that the ancients had defects. For example, Montesquieu warns that ancient authors should not always be taken "pour exactement vrayes"; because they used to manipulate the narrative according to their practical necessities. ${ }^{127}$ Indeed, the reasons why a philosopher or a writer could become famous in Antiquity changed since the invention of the press. ${ }^{128}$ However, although what can be learnt about and from ancient philosophers is limited, there are some exceptions, like Cicero: "Cicéron ne nous a donné que de la métaphysique et de la morale, et ce qu'il nous en a donné est parfaitement beau”. ${ }^{129}$

In fact, if Cicero and other ancients committed mistakes, they often "étoi[ent] la dessus dans la meme err[eur] que nous". ${ }^{130}$ In addition, they often had "lumier[es que] nous n'avons pas". ${ }^{131}$ That is why one cannot confuse their eventual misunderstandings with savage rusticity. Great nations and savages are different because "celles-là se sont appliquées aux arts et aux sciences, et que ceuxci les ont absolument négligés". ${ }^{132}$ Thus, as ancient cultural achievements remain relevant nowadays, what is possible to admit concerning modern superiority is that "les découvertes de ce siècle si admirables, ce ne sont pas des vérités simples qu'on a trouvées, mais des méthodes pour les trouver; ce n'est pas une pierre pour l'édifice, mais les instruments et les machines pour le bâtir tout entire". ${ }^{133}$ Montesquieu wants to say that one of the great modern merits is the introduction of new mechanisms of critical thinking, the free use of reason. And he verifies some of the traits of this critical approach in Cicero's philosophical critique.

Montesquieu reads the independent position promoted by the New Academy, of which Cicero declared himself an adept, as crucial to philosophical activ-

126 Fott 2002, 728.

127 Mont. Pensées 2.1308 (Dornier 2013): "For exactly true".

128 Mont. Pensées 2.899 (Dornier 2013).

129 Mont. Pensées 1.211 (Dornier 2013) (footnote): "Cicero only gave us metaphysics and morals, and what he gave us is perfectly fine".

130 Mont. Notes 73 (Benítez 2012): "Were above in the same error as us”, commenting Cic. nat. deor. 2.50 .

131 Mont. Notes 90 (Benítez 2012): "Lights that we don’t have”, commenting Cic. nat. deor. 3.24.62.

132 Mont. Discours sur les motifs 76 (Laboulaye 1879): "The former are applied to the arts and sciences, and the latter have absolutely neglected them".

133 Mont. Discours sur les motifs 79 (Laboulaye 1879): “The discoveries of this so admirable century are not simple truths that have been found, but the methods of finding them; it is not a stone for the building, but the instruments and the machines to build it as whole". 
ity, especially in discussions about religion. Fott tries to reformulate his earlier statement but ends up only observing a contradiction in Montesquieu's negative opinion on Cicero's dubious theoretical character. ${ }^{134}$ How can Cicero be a hesitant philosopher but adopt a sustainable method? In fact, I believe this is not a contradiction.

There are two possibilities to solve this problem. First, Montesquieu's reprobation results from a prejudice against Ciceronian academic skepticism, common at that time. If this alternative prevails, Montesquieu's Cicero would be concern only with dispelling errors to find the probable truth (since the truth itself is uncertain). However, he would never be able to offer any constructive proposals after destructing false knowledge. Considering Montesquieu's high praise of some of Cicero's reflections, this conclusion is clearly not correct. The second alternative then is to admit that Montesquieu's investigative approach adopts partially the Ciceronian method, at least when it comes to using different arguments with sincerity, contrasting different opinions to reconstruct complex realities. This interpretation seems correct especially when one realizes that Montesquieu reading of Cicero uses precisely this kind of approach, which allows him to acknowledge the author's intricate profile. Thus, he is not ungrateful to Cicero the ancient philosopher: not only Montesquieu recognizes that, despite his mistakes (natural in ancient minds), Cicero was a great spirit, but also assimilates his critical behavior.

Indeed, Cicero's letters written in exile display an important ancient quality: to put in the same terms great and small things. ${ }^{135}$ Somehow, this applies to modern men: always expecting great thinkers, they forget the popular function of philosophy, while "the wise men of antiquity" believed that "la sagesse devoit être commune à tous les hommes, comme la raison, et que, pour être philosophe, c'etoit assez d'avoir du goût pour la philosophie". ${ }^{136}$ Therefore, the moderns were not so superior to the ancients. Although very different, Caesar and Cromwell were both great men, so that "on ne peut pas dire que l'Anglois ait été inférieur au Romain par le genie". ${ }^{137}$ This, I reiterate, stems largely from the recognition of the ancients' intellectual autonomy, especially in Cicero.

134 Fott 2002, 730 -731. See Cic. nat. deor. 1.10; 3.95; Tusc. 5.11.

135 Mont. Pensées 1.117 (Dornier 2013).

136 Mont. Discours de réception 245 (Montesquieu 1796): "Wisdom should be common to all men, like reason, and that, to be a philosopher, it was enough to have a taste for philosophy". 137 Mont. Réflexions 180 (Montesquieu 1892): "One cannot say that the Englishman was inferior to the Roman by genius". 
For this reason, among his options of epigraph to De l'esprit des lois, Montesquieu listed "La loy est la raison du grand Jupiter. Cicéron De legibus". ${ }^{138}$ At the end, he preferred Ovid's Metamorphoses, Prolem sine matre creatam, ${ }^{139}$ which described well his impetus of innovation. ${ }^{140}$ Nevertheless, his cogitation on a Ciceronian sentence is relevant not only for its content, but for the author. As someone stripped of people's prejudices, ${ }^{141}$ Cicero accomplished much at a time when philosophical speculation was strange to the Romans, as they were occupied with “des arts de la guerre et de la paix". Philosophy only took place when it was made compatible with political, legal, and military activities, as he observes Cicero, the main figure in charge of that mission. ${ }^{142}$ Therefore, Montesquieu reiterates Cicero's role as a philosopher. In fact, as stated in Notes, if he had many rivals in eloquence, in philosophy he was the first:

Ciceron ne meritte pas moins le titre de philosophe que d'orateur romain on peut [dire] mesme qu'il s'est plus signalé dans le Licée que sur la Tribune, il est origin[al] dans ses livres de philosophie au lieu qu'il y a eu plusieurs rivaux de son éloquance il est le premier chez les Romains qui ait tiré la philosophie des mains des scavans et l'ait dégagée d[es] embarras d'une langue étrangere, il la rendit commune à touts les homes come la [raison] et dans l'applaudissement qu'il en reçut les savants se trouvèrent d'accord avec le peuple. ${ }^{143}$

His importance stands out even more when considering "la profondeur de ses raisonements”. The greatest proofs of this are his reflections on religion:

C'est une chose admirable de le voi[r] dans son livre de la nature des dieux se joüer de la philosophie meme et faire combatre ses champions entre eux de manière qu'ils se détruisent [aisément] les uns les autres celuy la est batu par celuy ci qui se trouve battu a so[n]

138 Mont. Pensées 3.1874 (Dornier 2013): “The law is the great Jupiter's reason. Cicero De legibus", citing Cic. leg. 2.4 .

139 Rosso 1983, 238.

140 Santos; Miranda 2016, 197; Althusser 1992, 7-8.

141 Mont. Notes 65 (Benítez 2012), commenting Cic. nat. deor. 1.81-83.

142 Mont. EL 23.21: "The arts of war and peace”, quoting, in footnote, Cic. off. 1.[150].

143 Mont. Notes 40 (Benítez 2012): "Cicero does not deserve the title of philosopher less than of Roman orator. One can say even that he is noted more in the Lyceum than on the Tribune. He is original in his books of philosophy. Instead, having several rivals of his eloquence, he was the first among the Romans who removed philosophy from the hands of the scholars and freed it from the embarrassment of a foreign language. He made it common to all men as reason, and in the applause that he received, the scholars found themselves in agreement with the people”. 
tour. Touts les sisthèmes s'evanouissent les uns devant les autres et il ne reste [dans] l'esprit du lecteur que du mepris pour le philosophe et de l'admiration pou[r le] critique. ${ }^{144}$

In other words, the Ciceronian approach contrasts different theoretical positions and makes their fragility and inconsistencies appear, so that philosophical systems would destroy themselves. Cicero's critical posture serves as a model for all those who intend to philosophize, since the free use of reason allows one to penetrate many speculative investigations without the concern of committing heresies or harmonizing with prevailing Christian precepts:

Je n'ay pu m'empecher en lisant ces merveilleux ouvrages de charger mes [marges] de quelques réflexions et je les ai faittes dans la liberté de la philosophie j'ay souvant fait abstraction d'une relligion que je revere, et come il est impossible d'estre philosophe et theologien tout ensemble, parce que ce qui es[t] selon l'ordre de la nature n'a point de raport à ce qui est selon l'or[dre] de la grace je me suis souvent mis à la place du pajen dont je lis[ais] les ouvrages bien résolu de rentrer aussi tost dans le devoir et de quitt[er] en sortant ces sentimens à la porte de mon cabinet. ${ }^{145}$

Montesquieu even corrects Cicero when he notes the Roman philosopher not following his own argumentative parameters. Commenting a passage from De divinatione, in which Cicero declared preference for Plato and his greater authority, Montesquieu observes that the real justification should be the rational superiority of Plato's arguments, that is, the criterion of authority is reason, not an abstract tradition. ${ }^{146}$ Cicero's passage is then reinterpreted in order to preserve the critical spirit praised by the Baron de la Brède.

Examining Notes, "we discover another Montesquieu", following the emergence of a new philosophical attitude, a new spirit among French intellectuals. Montesquieu, as the future lumières, is no longer a passive reader but an active

144 Mont. Notes 40 (Benítez 2012): "It is an admirable thing to see him, in his book On the nature of the gods, playing with philosophy itself and making its champions fight against each other so that they easily destroy each other. That one is beaten by this one, which is beaten in his turn. All the systems vanish one in front of the other and in the reader's spirit only remains contempt for the philosopher and admiration for the critic".

145 Mont. Notes 41 (Benítez 2012): "I could not help, when reading these wonderful works, to load my margins with some reflections and I did it in the freedom of philosophy. I have often disregarded a religion that I revere, and as it is impossible to be a philosopher and a theologian all together, because what is according to the order of nature has no relation to what is according to the order of grace, I have often put myself in the place of the pagan, from where I read the works, determined to quickly return to duty and to abandon these feelings, leaving them at my office door”.

146 Mont. Notes 108 (Benítez 2012), commenting Cic. div. 1.62. 
author, educated through the critical interpretation of classics. As VolpilhacAuger concludes, “Montesquieu, reader of Cicero, becomes annotator", someone who criticizes, accuses and acquires autonomy of philosophizing. ${ }^{147}$ Important for him is Cicero's critical stance towards philosophy, or as Benítez states, "Montesquieu's Cicero philosopher is the Cicero critic of the philosophy of the philosophers", someone who already had that critical approach to knowledge that characterizes modern superiority. Cicero's Cotta did this when dealing with Epicureanism and Stoicism in the discussion about the existence of gods. The result may not be a definitive conclusion in favor of a preexisting theoretical formulation, but is valid at least because it faces different arguments, fights superstitions, although not excluding possible uses that religion may have, as in Dissertation. The liberté de la philosophie is an explicit opposition to the restrictions of faith and to heterodox positions, moving away from masters' authority in favor of philosopher's autonomous thinking, without imposing a choice on readers, just as Cicero did. ${ }^{148}$ Montesquieu's portrait of Cicero in Discours can finally be summed up by the pensée 773's final sentence: “l'ame tôujours belle lorsqu'elle n'etoit pas foible". ${ }^{149}$ A statement not so negative considering the reception of Cicero in the rising Enlightenment. ${ }^{150}$

In fact, by the XVIII century Cicero had been a widely recognized and beloved figure of the intelligentsia, incessantly read and often called with an unusual intimacy as “Tully”. Besides Montesquieu, I have also mentioned Voltaire's passion. The enthusiastic connections with Cicero's life and legacy allows Sharpe to describe that period "as one of the highpoints in Cicero's reception". ${ }^{151} \mathrm{He}$ became a character of first importance in political and moral reflections, like Plutarch and Seneca. ${ }^{152}$ One of the possible reasons for this was a lumières' cherished conception: philosophe.

The philosopher writes academic treatises, but also engages in practical life, has a good knowledge of rhetoric, he is a truly litterateur. According to Sharpe, there was still a desire of challenging medieval opposition between vita activa and vita contemplativa, a process by which Cicero was the best example of reconciliation: he was not only the archetypal of civic philosopher and defender of res publica, but also a "philosopher who would inspire others to critical thought and action", like the lumières themselves. This was a romanticized representa-

147 Volpilhac-Auger 2013.

148 Benítez 2012, 15-16, 18.

149 Mont. Pensées 1.773 (Dornier 2013): "The soul always beautiful when it was not weak". 150 About Cicero during the French Enlightenment, see Berno (p. 370-371) in this volume.

151 Sharpe 2015, 334.

152 Volpilhac-Auger 1983, 79. 
tion of Cicero, as the one Montesquieu had in his youth. When listing the virtues of the old consul, he invariably ended up designing the ideal philosopher. ${ }^{153} \mathrm{~A}$ precise description of such ideal is the philosophe entry in the Encyclopédie.

In Dumarsais' text, probably retouched by Voltaire and Diderot, the philosopher is defined as someone who identifies causes and, if possible, predicts them. His mission is to identify the truth, as well as the false, doubtful or credible. In this process, "one of his great perfections is to remain undecided when he finds no suitable motive to judge". In fact, his "spirit consists in judging well", so he is content if the only way is to suspend his decision. Therefore, he does not "cling to a system to the point of not feeling the force of objections", that is, he opens up to the comprehensive, clear understanding of different opinions, even if he rejects them. ${ }^{154}$

Does Montesquieu and Voltaire's portrait of Cicero fit this definition? Had not even Fontenelle fulfilled this ideal before them, when he compared himself to Cicero, a model of philosophical diffusion, as in his new type of work that dealt with philosophy in a non-philosophical way? ${ }^{255}$ Or Pierre Bayle, taken by Montesquieu as the embodiment of the philosopher's model according to Cicero? ${ }^{156}$ The dialogue with Cicero by all these authors is no coincidence. As Gay observes, the two main Roman sources of inspiration for the lumières were Lucretius and Cicero. While the former provided them with slogans and attitudes, "their real favorite, Cicero, gave them even more - a philosophy". ${ }^{157}$

In particular, for Montesquieu, Cicero is part of another model for his own reflections: Roman constitutional structure, partially studied in Romains, and echoed in De l'esprit. According to him, following Polybius, ${ }^{158}$ and also Cicero, ${ }^{159}$ power was not concentrated, but divided between the spirit of the people, the strength of the senate, and the authority of certain magistrates. ${ }^{160}$ There was control of abus du pouvoir: "Rome avait des institutions admirables. Elle en avait deux surtout: par l'une, la puissance législative du peuple était réglée; par l'au-

153 Sharpe 2015, 345-346, 348.

154 Dumarsais 2015, 291-292.

155 Fontenelle 1686, preface: "Je suis à peu près dand le mesme cas où se trouva Ciceron, lors qu'il entreprit de mettre en latin des matieres de philosophie, qui jusque-là n'avoient esté traitées qu'en grecs" ("I am more or less in the same case in which Cicero found himself, when he began to put in Latin subjects of philosophy, which until then had been treated only in Greek").

156 Benítez 2012, 17.

157 Gay 1967.

158 Mont. Pensées 3.1672 (Dornier 2013).

159 Santos/Oliveira 2016.

160 Mont. Romains 67-68 (Montesquieu 1796). 
tre, elle était bornée”. ${ }^{161}$ But political factions later degenerated the balanced configuration and ruined the Republic. ${ }^{162}$

Republican Rome is a model, just as Cicero is a paragon of civic philosopher. Concerning the separation of powers, English constitution is corrected by the lessons of the Romans. In contrast, Cicero the philosopher enables the evaluation of current philosophical positions and, as scholar engaged in practical political life, "draws people to virtue without preaching to them". ${ }^{163}$ If it was an idealized view, which confused "what Cicero had wished to be for what he actually was", at least it reveals what the lumières thought "a philosopher should be: the thinker in action", with political and moral qualities, as a "dutiful, upright citizen”, with "that most elusive of antique philosophical ideals - humanism". ${ }^{164}$ As Rosso observes, Montesquieu is a humanist who worshipped Antiquity, living in "constant cohabitation with the ancients", ${ }^{165}$ in a century when Cicero's humanitas was reappearing, permeating key conceptions from Voltaire to Kant. ${ }^{166}$ However, considering the early experience of rise and fall of Ciceronianism, Montesquieu did not develop a humanism based on literary style or moral superiority. His Latin heritage had been subjected to a historical and critical re-examination, something that made it impossible to resurrect the past. Montesquieu's humanist Ciceronianism must include Cicero as citizen, magistrate, orator and philosopher, object of praise, but also flawed and subject to criticism, without losing its exemplary status. ${ }^{167}$

What is still valid from Cicero's exemplarity is his intellectual autonomy and struggle for universal recognition. If there are paradoxical aspects in this portrait, those elements mentioned above are precisely what makes Cicero compatible with Montesquieu's perspective on philosophical research and what stimulated his own intellectual paths. Although he credited the moderns with some superiority, Cicero continued to be admired: as proclaimed in Discours, the consul was the ancient who "a eu le plus de mérite personnel, et qui j'aimerois mieux ressembler". 168

161 Mont. EL 11.16: "Rome had admirable institutions. It had above all two: by one, the legislative power of the people was regulated; by the other, it was limited".

162 Mont. Pensées 1.371 (Dornier 2013).

163 Fott 2002, 729.

164 Gay 1967.

165 Rosso 1983, 240.

166 Gay 1967.

167 Rosso 1983, 245-246.

168 Mont. Discours sur Cicéron 1 (Montesquieu 1892): "Had the most personal merit, and who I would like better to resemble". 


\section{Conclusion}

Cicero is used as a historiographical source, political actor and philosopher in Montesquieu.

As a historiographical source, Cicero is one of the most quoted authors, although not merely as an exempla reservoir. History as magistra vitae was a declining paradigm. The doors were open to philosophy of history. Montesquieu was an undisputed contributor to future historiography, as manifested in his zeal in dealing with sources. Cicero and other ancient authors then reappear as still useful for modern men, permeating works like De l'esprit des lois, described by Gay as "a massive tribute to antique thought" which "supports its generalizations with numberless allusions to ancient politics". ${ }^{169}$

As a political actor, Cicero is considered halting, responsible for grave errors. For this reason, his ethical role is sometimes small. However, he died as a martyr dedicated to civic duties lamentably lost in Modern Age. Despite his flaws, it was through his political activity that he became a great character in history. If Montesquieu's reproofs are consistent, they do not overshadow the other dimensions.

As a model of philosopher, Cicero performs reflective activity in a critical and independent perspective, as evidenced and exalted by Montesquieu, especially in his discussions on religion. Although most of these texts were written in his youth, they allow us to reconstruct some fundamental steps of his process of intellectual formation. Many elements and opinions born in comments, unfinished manuscripts, fragments, and scattered thoughts will follow Montesquieu throughout his trajectory. As Roman Republic was a model for political thinking, Cicero also seemed to him a parameter of great philosopher, essential for another would-be philosopher. On the one hand, Rome urged Montesquieu to confront the complexity of reality in its totality, the true task of a philosopher. Maupertuis was precise in describing this pretension: "Après avoir considéré les effets des passions dans l'homme pour ainsi dire isolé, M. de Montesquieu les considéra dans ces grandes collections d'hommes qui forment les nations, \& choisit pour cela la nation la plus fameuse de l'Univers, les Romains". ${ }^{170}$ On the other hand, Cicero urged Montesquieu to deal with reality by a plurality of philosophical approaches, that is, to have critical attitude, which implied comparing, opposing, refuting, confirming, revaluating, even refraining from concluding. But

169 Gay 1967.

170 Maupertuis 1756, 399: “After having considered the effects of passions in man, so to speak, isolated, Mr. de Montesquieu considered them in these great collections of men that form the nations, and chose for this purpose the most famous nation in the Universe, the Romans". 
since Cicero was also a model of civic philosopher, he shows the meaning of true political philosophy, which can, for example, condemn religions in its theological grounds, but recognize its utility as instrument of social control.

Montesquieu, "naturellement curieux de tous les fragments des ouvrages des anciens auteurs", ${ }^{171}$ had Cicero as his supreme exemplar of philosophical and political excellence.

171 Mont. Pensées 1.773 (Dornier 2013): "naturally curious about all fragments of the works of the ancient authors". 
